\title{
EXPLORING TRUST IN TSUNAMI EVACUATION DECISION: AN INITIAL STUDY
}

\author{
Hilya Mudrika Arini \\ Departemen Teknik Mesin dan Industri, Fakultas Teknik \\ Universitas Gadjah Mada \\ Jalan Grafika No. 2, Yogyakarta 55281 \\ hilya.mudrika@ugm.ac.id
}

\begin{abstract}
This initial study explores the importance of trust in Aceh tsunami evacuation. Drawing upon the cultural theory as theoretical basis, this research classifies people in Aceh based on their trust level and identifies the significant factors influencing them to trust to different sources during tsunami. To accomplish the goals, an offline survey to 62 respondents in Aceh who experienced tsunami was conducted. From this survey, it found that most of respondents tend to be more trust to their self (individualist) and family/neighbor (egalitarian) than trust to government (hierarchy) and religious leader (traditional). On the other hand, (1) self-efficacy, (2) evacuation knowledge and (3) trust level to non-government people are indicated as the significant factors influencing people to trust in different sources during tsunami evacuation. This initial result will be benefit to develop a predictive model of trust using Agent-based model and simulation (ABMS) for the further research.
\end{abstract}

Keyword: Behavioral Operations Research, Evacuation Decision, Cultural Theory, Agentbased Model and Simulation (ABMS).

\section{Abstrak}

Studi pendahuluan ini mengeksplorasi pentingnya perilaku kepercayaan dalam evakuasi tsunami di Aceh. Dengan mengacu pada teori budaya, penelitian ini mengklasifikasikan orang-orang di Aceh berdasarkan tingkat kepercayaan dan mengidentifikasi faktor-faktor yang signifikan yang memengaruhi mereka untuk percaya pada beberapa sumber informasi selama tsunami terjadi. Untuk mencapai tujuan tersebut, survei offline kepada 62 responden di Aceh yang pernah mengalami tsunami dilakukan. Dari survei ini, ditemukan bahwa sebagian besar responden cenderung lebih percaya pada kemampuan mereka sendiri (individualis) dan keluarga/tetangga terdekat (egaliter) daripada kepada pemerintah (hierarki) dan pemimpin agama (tradisional). Di sisi lain, (1) tingkat kepercayaan diri, (2) pengetahuan mengenai evakuasi dan (3) tingkat kepercayaan kepada orang-orang non-pemerintah diindikasikan sebagai faktor signifikan yang memengaruhi orang di Aceh untuk percaya pada sumber informasi yang berbeda selama evakuasi tsunami. Hasil studi pendahuluan ini nantinya akan digunakan untuk mengembangkan model prediksi kepercayaan masyarakat di Aceh selama tsunami menggunakan Agent-based Modeling and Simulation (ABMS) untuk penelitian selanjutnya.

Kata Kuci: Behavioural Operations Research, Keputusan Evakuasi, Teori Budaya, Agentbased Modeling and Simulation (ABMS).

\section{Introduction}

Indonesia is a country that has a high potential for natural disasters because of its location in the Pacific Ring of Fire and four continental plates. Unfortunately, even though 
the level of risk of disasters is relatively high, the level of community and government preparedness in anticipating the impact of natural disasters still tends to be low. One form of lack of preparedness can be seen in the community's preparation for evacuating when natural disasters occur. In the 2004 Aceh tsunami, for example, approximately 60,000 people from the total population died due to the tsunami waves. This is partly because the community did not evacuate when the tsunami occurred.

[1] stated that the differences in the level of belief in a phenomenon in each different culture could influence the community's decision to evacuate the 2004 Aceh tsunami. In this study three tribes namely Aceh, Minangkabau and Simeulue on Simeulue Island compared to their behavior in conducting evacuation. According to the survey, the people of the Simeuleu tribe believe that natural phenomena that occur are signs of a tsunami so that they can evacuate to mountains or higher ground as early as possible. In this tsunami disaster, only 44 people from the Simueule tribe were found victims. In contrast to the people of the Simeule tribe, people from Aceh and Minangkabau do not believe in the phenomenon so much that they cannot detect tsunamis as early as possible. In this disaster 170,000 people from the Aceh and Minangkabau tribes on Simeulue Island were affected. From this research it is proved that differences in beliefs in each culture can influence community evacuation decisions when natural disasters occur.

[2] stated that the cultural theory developed by Douglas in 1978 can be used as a foundation in classifying public trust. In addition, according to [3] community trust can affect their willingness in relation to decision making during evacuation. For example, when people believe in evacuation instructions given by the government, they will immediately follow government instructions for evacuation.

According to cultural theory, people's trust can be categorized into four groups. First, the 'individualist' prefers less regulation by the government. People in this group are relatively free from control by other people and institutions, and strive to exert control over their environment and the people in it. Their success is often measured by their wealth and the number of followers they can command. Second, people in the 'hierarchy' group have strong loyalties and respect for strong group boundaries and binding prescriptions. They believe that rules and regulations enable one to handle uncertainty. Social relationships in this group are hierarchical, with everyone knowing their place. The third group, the 'egalitarians', unlike the hierarchy group, have high group loyalty but little respect for externally imposed rules, other than those imposed by nature. Group decisions are arrived at democratically and leaders rule by force of personality and persuasion. The finally group, 'fatalists', have minimal control over their own lives. They belong to no groups that are responsible for the decisions that rule their lives. They tend to be non-unionized employees, outcasts, and 'untouchables'. They are resigned to their fate, and they see no point in attempting to change it.

Unfortunately, there is limited study that explore the application of cultural theory in the context of trust in emergency evacuation decision. Therefore, this study employs the cultural theory as a basic theory to identify people trust during tsunami in Aceh, Indonesia. On the other hand, this study also investigates the essential factors influencing people to decide to trust different sources during evacuation in tsunami.

\section{Literature Review}

\subsection{People Behaviour in Emergency Evacuations}

Fundamentally, there are four sequential-operational stages in the disaster management cycle, namely the mitigation, preparation, response, and recovery stages [4]. 
Regarding the sequential-operational stages in the disaster management cycle, evacuation activity is usually conducted during the response stage. [5] states that this activity is essential as it can result in the preservation of life, reduction of personal injury, and the protection of property. Accordingly, considering the importance of evacuation, an evacuation strategy has to be developed that is as good as possible in order to respond to such disasters.

However, although the government has prepared and implemented an evacuation strategy, there are some people who are relatively hard to engage in the evacuation activity when disasters occur. According to a study by [6], this might happen due to their different human behavior. The researchers claimed that human behaviors are somewhat random and difficult to model since different people would have different perceptions of danger and would react differently to emergencies. Moreover, [7] states that, when facing difficulties during evacuation, people will normally blame the groups and government that have responsibility for and are carrying out the evacuation. Consequently, in the process to develop an evacuation strategy, the government should seek to fully understand people's behavior and the factors motivating them to engage in the evacuation process during a disaster.

A study conducted by [8] stated that physical factors, such as age, gender, and body dimensions, influence the likelihood of people evacuating during disaster situations. In their study, for example, they found that elderly people are relatively difficult to evacuate due to health issues that mean their speed and mobility during an evacuation process are reduced. However, this conclusion cannot be generalized, and other studies have presented different results [9-12] from [8]. A study conducted by [11], for example, failed to find a consistent relationship between socio-demographic factors (i.e. age, income, education, gender, race, and children) and evacuation decisions. Another study also found that younger people, and males in particular, were more likely to choose not to evacuate [12].

A study conducted by [7] examined another motivation to evacuate. He argued that the reluctance to evacuate is motivated by the psychological factors, where individuals under stress and with less self-efficacy typically consider which would be the least disruptive behavioral option in the situation. Therefore, instead of relying on their own decisionmaking, people sometimes interact with others and make a collective decision regarding whether to evacuate.

To support this theory, some studies have examined the social interactions between people during an emergency evacuation. A study conducted by [13] pointed out that people will confirm their friends, relatives, and neighbors once they receive the initial warning from the government; if their friends, relatives, and neighbors decided not to evacuate, they might follow them and not evacuate either.

In light of the above-mentioned behaviors and motivations identified in past studies, it will still be difficult for the government to ensure that all people perceive the same danger from a disaster and follow the government evacuation strategy, as relevant behaviors and motivations will vary between individuals.

Therefore, to ensure each individual perceives risk in the same way, which is needed in order for them to follow the evacuation strategy, the government should ensure risk communication is as effective as possible. A study by [14] also argued that good risk communication can prevent people from amplifying or attenuating the risk event. To ensure good risk communication, [15] suggests managing the contributors to amplification (e.g. the government warning and information), ensuring the reliability of information sources and the credibility of warning systems [16]. [16] also claimed that if the government fails to provide reliable and credible information during an emergency situation, people will distrust them and attempt to find other sources of information that they consider more personally relevant, and will assess their own risk. In line with [16], [17] also examined trust in information 
providers; they claimed that the information source is of critical importance with respect to risk communication. The following section will detail the role of trust in risk communication during emergency evacuations.

\subsection{The Role of Trust in Risk Communication in Emergency Evacuations}

As discussed in the previous section, people can have different perceptions of risk that lead them to behave differently. This might be because they understand and interpret the information and the warning they receive from the government in different ways. On the other hand, the lack of risk communication is also expected to affect people's risk perception. In other words, effective risk communication is important in a crisis situation; allows the public to respond to crisis events and also lowers the possibility of incorrect information being disseminated. A serious result of risk communication failure or miscommunication is a potential crisis situation.

The studies conducted by [18], [19], and [20], all state that trust is key to successful risk communication. It can mediate the relationship between people's beliefs and the source of information [21]. If risk managers are trusted then communication is relatively easy; however, if there is no trust in the risk manager, communication will not be successful. [22] also add that it can enable the public to respond to crisis events quickly and also lowers the possibility of incorrect information being provided.

According to psychological perspectives, trust is defined as "a psychological state comprising the intention to accept vulnerability based upon positive expectations of the intentions or behavior of another" [23]. However, because this study focuses on trust in the context of risk communication, the definition of trust by [19] is more appropriate for adoption in this study, according to which, "trust in communication refers to the generalized expectancy that a message received is true and reliable and that the communicator demonstrates competence and honesty by conveying accurate, objective, and complete information."

[19] stated becoming a trusted risk communicator and gaining trust are difficult. Additionally, even if people are able to become a trusted risk communicator, it is difficult for them to maintain that trust. A study conducted by [24] also found that culture may also influence whether people trust warnings in emergency conditions. Their study found that Japanese people are more likely to respond to the volcano warnings than people from the U.S. This is because Japanese people live within a collectivist culture in which citizens have higher expectations that authorities will provide care in the event of a disaster or other disruptions to social life. The authors also suggested that the Japanese population overall has a greater trust in their government, and thus exhibits greater response rates than Western societies; this also reflects the broader cultural rules of obedience and authority that are common in Asian societies. To detail the cultural influencing trust, the following section will discuss the cultural theory as a basic theory in this study.

\subsection{Cultural Theory}

This section will discuss cultural theory, which can be used to understand individual trust and the cultural group to which individuals belong. Cultural theory draws upon both anthropology and sociology [25]. It was mentioned in a seminal book by Douglas in 1966, and introduced in her later, important work in 1978. According to this theory, people's risk perceptions are influenced by the cultural group to which they belong. The theory gets 
somewhat closer to understanding the risk perception of lay persons by providing a systematic view of the widest range of goals that those people might be seeking to achieve.

There are a distinct number and definitions of groups in cultural theory. [26] also pointed out that these are inconsistent in the existing literature, and depend on the researcher's perspective. Some researchers identify four groups: fatalists/isolates; hierarchy; individualists; and egalitarians. Others define five groups: atomized individuals; bureaucrats; entrepreneurs; egalitarians; and hermits [27-28] Each group has distinct aspects that differentiate between how each group constructs and selects risks. Additionally, [29] stated that each group argues rationally, has separate world views, and a certain position on risk . They also have defined coping mechanisms and attitudes. Therefore, the group can be used to predict individual responses.

In one version of cultural theory, four groups are defined. The first group, the individualists, prefers less regulation by the government. People in this group are relatively free from control by other people, and strive to exert control over their environment and the people in it. Their success is often measured by their wealth and the number of followers they can command. People in the hierarchy group, on the other hand, have strong loyalties and respect for clear group boundaries and binding prescriptions. They believe that rules and regulations help to cope with uncertainty. Social relationships in this group are hierarchical, with everyone knowing his or her place. Unlike the hierarchy group, the egalitarians have strong group loyalties but little respect for externally imposed rules, other than those imposed by nature. Group decisions are arrived at democratically and leaders rule by force of personality and persuasion. Fourth, the fatalists have minimal control over their own lives. They belong to no groups responsible for the decisions that rule their lives; they are nonunionized employees, outcasts, and untouchables. They are resigned to their fate and see no point in attempting to change it.

Unfortunately, even though cultural theory has been introduced a long time ago, yet, there is still limited study who link between cultural theory and trust behavior in the context of emergency evacuation. Most studies only attempt to classify people based on four categories in cultural theory [30-31].

\section{Methodology}

In order to accomplish the objectives, this study performed offline survey to people who experienced 2004 tsunami in Aceh, Indonesia. Firstly, the questionnaire was developed based on the existing literature and adjusted in the Indonesian context. In the questionnaire, the respondents were asked their trust decision during tsunami evacuation. There are five possible answer, i.e. (1) trust to their self that is defined as individualist in this study, (2) trust to government (i.e. hierarchy), (3) trust to neighbor and family (i.e. egalitarian), (4) trust to religious leader (i.e. traditional) and (5) trust to their fate (i.e. fatalist). These answers, in the further analysis, will be considered as dependent variable. On the other hand, respondents were also administered to fill some questions as independent variables, such as their sociodemographics (i.e. gender, age, education status, residence status, the number of family member, and private transportation), evacuation knowledge, and physiological factor in five Likert-scale (i.e. risk perception, self-efficacy, trust level to government and nongovernment, family consideration and neighbor consideration). However, before the questionnaire is utilized, pilot test to four experts in behavioral operations research is conducted to validate face and content of the questionnaire.

From offline survey, there were 70 respondents in Aceh who were willing to participate. However, after data cleansing, eight respondents were not considered because of 
they did not fill the questionnaire completely. From 62 available data, non-parametric test was conducted to identify people based on their different trust behavior and to obtain the significant factors contributing people to trust different sources in emergency evacuation. Finally, the survey result is compared to the existing literature in order to discuss the empirical finding based on theoretical view.

\section{Result and Discussion}

\subsection{Profile of Respondent}

There are 62 respondents who have various background on their socio-demographics profile, namely gender, age, residence status, and education status. First, regarding their gender, $74 \%$ of respondents are female and the rest of them are male. The portion of female respondents are majority because this survey was conducted during the day where most of male respondents are working.

According to Fig. 1, it depicts that most of respondents trust to their own self (individualist). However, the interesting result is located on hierarchy category. It shows that none of male in this study trust to the government during tsunami in Aceh. Most of them trust to their capability (i.e. individualist) and their family/neighbor (i.e. egalitarian). Only a few of them trust to religious leaders (i.e. traditional).

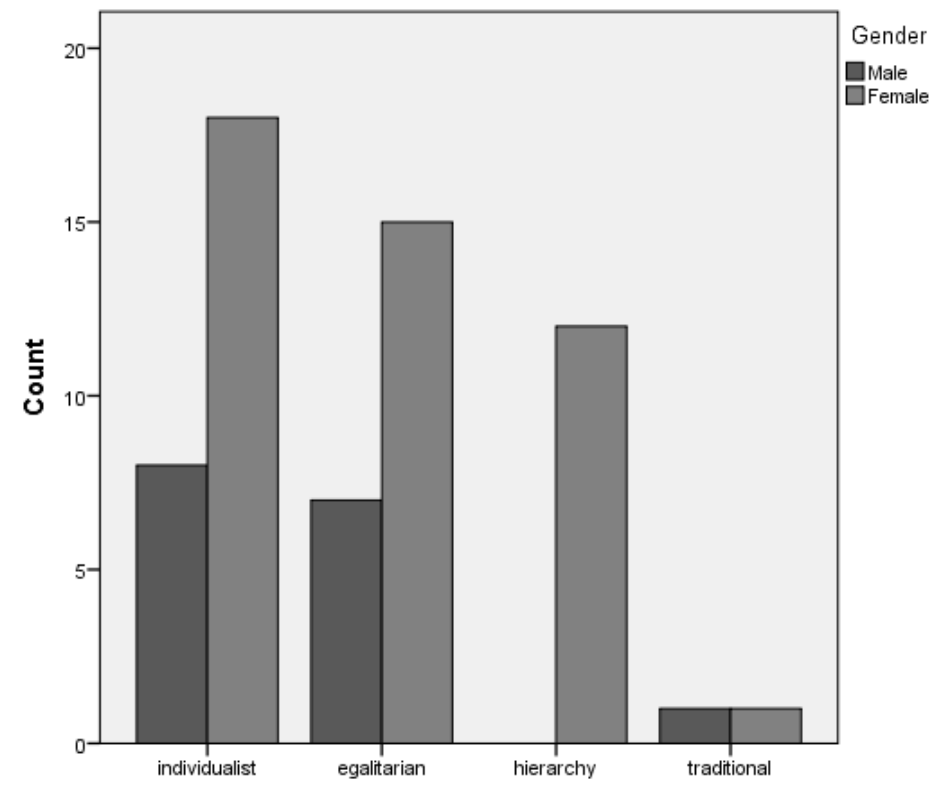

Fig. 1. Descriptive result of gender comparison in trust during tsunami

Second, the age average of respondents are 35 years old. The oldest participant is 57 years old and the youngest participant is 20 years old. Third, based on residence status, $82 \%$ of respondents are permanent residents and hence all respondents have tsunami experience. Additionally, regarding Fig. 2, both permanent resident and immigrant trust sequentially to their self (i.e. individualist), family/neighbor (i.e. egalitarian), and government (i.e. hierarchy). Only a few respondents and none of immigrant trust to religion leader. 


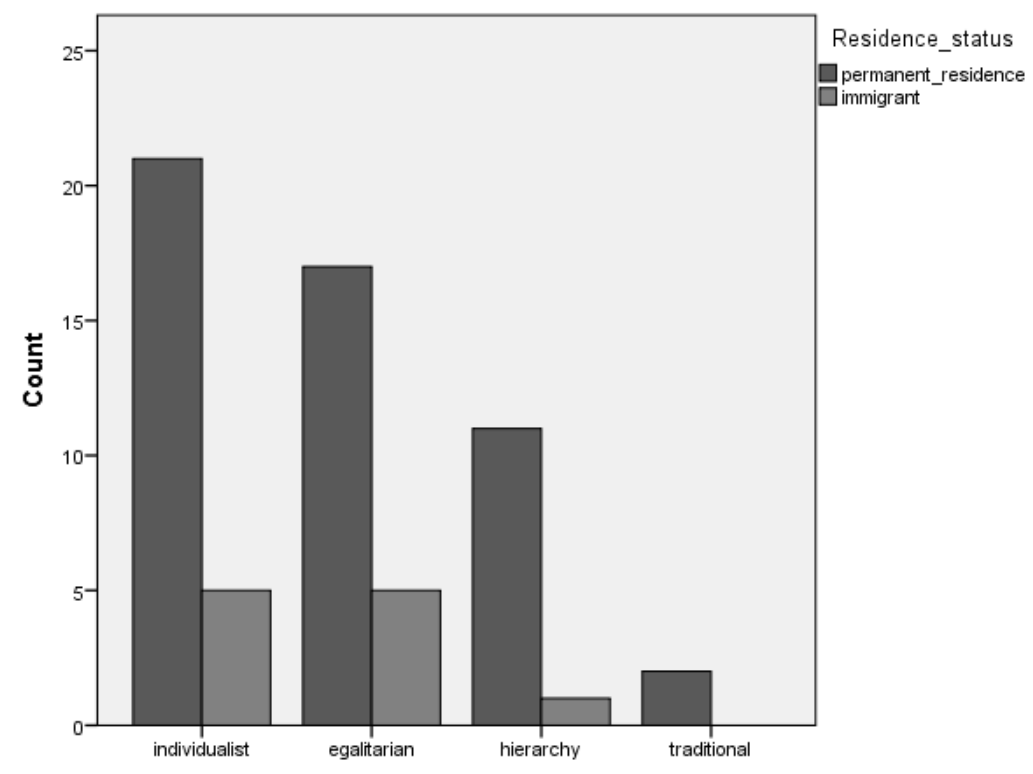

Fig. 2. Descriptive result of residence status comparison in trust during tsunami

Fourth, considering the respondent's education status, most of them have a good education level. It is depicted on $37 \%$ of respondents have completed education in senior high school and $48 \%$ of them are awarded undergraduate degree. Therefore, based on their education status, their understanding to fill the questionnaire is undoubtable.

\subsection{Trust during Tsunami Evacuation in Aceh}

In this study, there are 13 factors that are investigated as shown in Table 1 . However, only three significant factors influencing people in their trust behavior during tsunami in Aceh, namely (1) self-efficacy, (2) evacuation knowledge and (3) trust level to nongovernment people.

First, considering statistical result as shown in Table 1, self-efficacy is indicated as a significant factor influencing people to have different trust behavior. Self-efficacy is defined as people' belief in their own ability to succeed in specific situations or accomplish a task. This is in line with the study conducted by [32] who investigate the relation of self-efficacy in flood preparedness intention. Their study revealed that an individual will assess their own competence prior to respond the risk of disaster. If they believed that their own skills, knowledge and resources can perform the preparedness action to minimize the risk of disaster, they will do the preparedness by their self. Conversely, if they considered that they do not have enough skills and knowledge, such as they do not understand the evacuation route, thus, they will rely on the others to perform the preparedness action to minimize the risk of disaster. A study conducted by [7] also stated that individual with less self-efficacy typically consider which would be the least disruptive behavioral option in the situation. Therefore, instead of relying on their own decision-making, people sometimes interact with others and make a collective decision regarding whether to evacuate. In other words, people who have high self-efficacy tend to be individualist whilst they tend to be hierarchy (i.e. trust to the government), egalitarian (i.e. trust to the family and neighbor), or fatalist (i.e. trust to fate) when they have less self-efficacy. 
Table 1. The statistical result

\begin{tabular}{|l|l|l|}
\hline No. & Variable & $\mathrm{p}-$ value \\
\hline 1. & Age & 0.397 \\
\hline 2. & Education status & 0.641 \\
\hline 3. & The number of family member & 0.865 \\
\hline 4. & Risk perception & 0.169 \\
\hline 5. & Self-efficacy & 0.046 \\
\hline 6. & Trust level to government & 0.117 \\
\hline 7. & Trust level to non-government people & 0.041 \\
\hline 8. & Family consideration & 0.356 \\
\hline 9. & Neighbour consideration & 0.919 \\
\hline 10. & Gender & 0.137 \\
\hline 11. & Residence status & 0.665 \\
\hline 12. & Evacuation knowledge & 0.050 \\
\hline 13. & Private transport & 0.497 \\
\hline
\end{tabular}

Second, evacuation knowledge also becomes the significant factor affecting people to trust different sources during tsunami Aceh. This finding is similar to the study conducted by [33] that investigate a fire evacuation in a cinema theatre. They state that people who have lack information in the fire cue, thus social influence will be an important factor. Therefore, in line with [33], it is not surprising that the evacuation knowledge highly affects people to have different trust behavior during tsunami. People who have evacuation knowledge will become individualist and independent to decide then people who have lack of knowledge.

Third, trust level to non-government people is also considered as an essential factor influencing people to trust differently. It is also found that people who tend to trust to their family, neighbor and public figure (egalitarian) have higher score in this factor than people who are individualist or hierarchy (trust to the government). It is in line with [34] who investigate the impact of spiritual leader in the Merapi volcano in Yogyakarta, Indonesia. In [34], egalitarian tend to have high trust level to non-government people, such as spiritual leader. Therefore, when Merapi volcano occurred in 2010, most people died because they trusted and followed the decision of spiritual leader. 


\section{Conclusion and Future Work}

This study highlights the importance of human trust behavior in evacuation decision during tsunami in Aceh. From this study, it found that there are three significant factors affecting people to trust different sources, namely (1) self-efficacy, (2) evacuation knowledge and (3) trust level to non-government people. On the other hand, acknowledging the result in this study, sequentially, most of people in Aceh: (1) trust to their own capability (39\%), (2) trust to family/neighbor (39\%), (3) trust to government (19\%) and (4) trust to religious leader (3\%) when tsunami occurred. This result indicated that most of people in Aceh are more trust to their self and their family/neighbor than the government when tsunami occurred. This fact also provides a warning to Indonesian National Disaster Management Agency (BNPB) to be more concern in improving strategy in order to increase people trust towards their emergency evacuation policy.

Unfortunately, this study is only an initial step of a continuous studies in investigating human trust behavior during tsunami evacuation in Indonesia. In the future, some following studies, e.g. development of a predictive model of trust in Aceh tsunami using Agent-based modeling and simulation (ABMS), will be developed based on the initial study that has been conducted, by adding the number of respondents and other characteristics of respondents.

\section{Daftar Pustaka}

[1] Gaillard, J. C. et al., 2008, Ethnic groups response to the 26 December 2004 earthquake and tsunami in Aceh Indonesia, Nat Hazards, 47, pp. 17-38.

[2] Marris, C., Langford, I. H. and O'Riordan, T., 1998, Risk perception_Cultural Theory Comparison with the Psychometric Paradigm, Risk Analysis, 18(5), pp. 635-647.

[3] Ajzen, I., 1985, Behavioral Interventions Based on the Theory of Planned Behavior, Action Control, pp. 11-39. doi: 10.1007/978-3-642-69746-3_2.

[4] Chatfield, A. T. and Brajawidagda, U., 2013, Twitter Early Tsunami Warning System: A Case Study in Indonesia's Natural Disaster Management, 2013 46th Hawaii International Conference on System Sciences, pp. 2050-2060.

[5] Perry, R. W., 1979, Evacuation Decision-Making in Natural Disasters, Mass Emergencies, pp. 25-38.

[6] Ben, X. et al., 2013, Agent-based Approach for Crowded Pedestrian Evacuation Simulation, IET Intelligent Transport Systems, 7(1), pp. 55-67.

[7] Quarantelli, E. L., 1990, The Warning Process and Evacuation Behaviour: The Research Evidence - Preliminary Paper \#148', pp. 1-14.

[8] Pan, X. et al., 2006, Human and Social Behavior in Computational Modeling and Analysis of Egress, Automation in Construction, 15(4), pp. 448-461.

[9] Aguirre, B. E., 1991, Evacuation in Cancun during Hurricane Gilbert, International Journal of Mass Emergencies and Disasters, 9(1), pp. 31-45.

[10] Baker, E. J., 1991, Hurricane Evacuation Behavior, International Journal of Mass Emergencies and Disasters, pp. 287-310.

[11] Stein, R. M. and Osorio, L. D., 2010, Who Evacuates When Hurricanes Approach?? The Role of Risk, Information, and Location, Department of Political Science Department of Computer Science', 91(3).

[12] Horney, J. a. et al., 2010, Individual Actual or Perceived Property Flood Risk: Did It Predict Evacuation From Hurricane Isabel in North Carolina, 2003?, Risk Analysis, 30(3), pp. 501-511.

[13] Drabek, T. E., 1969, Social Processes in Disaster: Family Evacuation, Social Problems, 16(3), pp. 336-349.

[14] Busby, J. and Onggo, S., 2012, Managing the Social Amplification of Risk: A Simulation of Interacting Actors, Nature Publishing Group, 64(5), pp. 638-653. 
[15] Bakir, V., 2005, Greenpeace v. Shell: media exploitation and the Social Amplification of Risk Framework (SARF), Journal of Risk Research, 8(7-8), pp. 679-691.

[16] Dow, K. and Cutter, S. L., 1998, Crying Wolf: Repeat Responses to Hurricane Evacuation Orders, Coastal Management, 26(4), pp. 237-252.

[17] Siegrist, M. and Cvetkovich, G., 2000, Perception Of Hazards: The Role of Social Trust and Knowledge, Risk Analysis, 20(5), pp. 713-719.

[18] Siegrist, M. and Zingg, A., 2014, The Role of Public Trust During Pandemics: Implications for Crisis Communication, European Psychologist, 19(1), pp. 23-32.

[19] Renn, O. and Levine, D., 1991, Credibility and Trust in Risk Communication, Communicating Risks to the Public, pp. 175-218.

[20] Breakwell, G. M., 2000, Risk Communication: Factors Affecting Impact, British medical bulletin, 56(1), pp. 110-20.

[21] Paton, D., 2007, Preparing for Natural Hazards: The Role of Community Trust, Disaster Prevention and Managementt: An International Journal, 16(3), pp. 370-379.

[22] Morgan, M. G. et al., 2000, Categorizing Risks for Risk Ranking, Risk analysis?: an official publication of the Society for Risk Analysis, 20(1), pp. 49-58.

[23] Rousseau, D. M. et al., 1998, Not So Different After All: A Cross-Discipline View of Trust, Academy of Management Review, 23(3), pp. 393-404.

[24] Perry, R. W. and Lindell, M. K., 2008, Volcanic Risk Perception and Adjustment in a Multi-Hazard Environment, Journal of Volcanology and Geothermal Research, 172(34), pp. 170-178.

[25] Hirsch, R. A. and Baxter, J., 2011, Context, Cultural Bias, and Health Risk Perception: the "Everyday" Nature of Pesticide Policy Preferences in London, Calgary, and Halifax, Risk Analysis, 31(5), pp. 847-865.

[26] Renn, O., 1992, Concepts of Risk: A Classification, Social Theories of Risk, pp. 53-79.

[27] Dake, K., 1991, Orienting Dispositions in the Perception of Risk: An Analysis of Contemporary Worldviews and Cultural Biases, Journal of Cross-Cultural Psychology, 22, pp. 61-82.

[28] Renn, O., 2008, Concepts of Risk: An Interdisciplinary Review Part 2: Integrative Approaches, Gaia, 17(2), pp. 196-204.

[29] Boholm, Å., 1998, Comparative Studies of Risk Perception: A Review of Twenty Years of Research, Journal of Risk Research, 1(2), pp. 135-163.

[30] Tansey, J. and O'riordan, T., 1999, Cultural Theory and Risk: A Review, Health, Risk \&amp; Society, 1(1), pp. 71-90.

[31] Brenot, J., Bonnefous, S. and Marris, C., 1998, Testing the Cultural Theory of Risk in France, Risk Analysis, 18(6), pp. 729-739.

[32] Samaddar, S. et al., 2014, Outcome-Expectancy and Self-Efficacy: Reasons or Results of Flood Preparedness Intention?, International Journal of Disaster Risk Reduction, Elsevier, 8, pp. 91-99.

[33] Nilsson, D. and Johansson, A., 2009, Social Influence during the Initial Phase of A Fire Evacuation-Analysis of Evacuation Experiments in A Cinema Theatre, Fire Safety Journal, 44(1), pp. 71-79.

[34] Arini, H.M., Bedford, T., Quigley, J., and Burns, C., 2017, Clustering People Trust Behavior in Emergency Evacuation: Evidence From Sinabung Volcano Eruption. Winter Simulation Conference (WSC), IEEE, pp. 4475-4476. 